\title{
EVALUATION OF HYDROPONIC FODDER PERFORMANCE OF DIFFERENT VARIETIES OF SORGHUM
}

\author{
Zelalem Garuma 1, Kassahun Gurmessa *2 ${ }^{*}$ iD \\ ${ }^{1}$ Oromia Regional State office of Agriculture and Natural Resource \\ ${ }^{* 2}$ Wollega University College of Agriculture and Natural Resource, Department of Animal Science
}

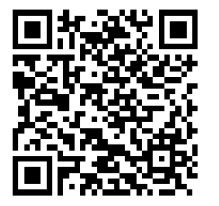

DOI: https://doi.org/10.29121/granthaalayah.v9.i2.2021.2854

Article Type: Research Article

Article Citation: Zelalem Garuma, and Kassahun Gurmessa. (2021). EVALUATION OF HYDROPONIC FODDER PERFORMANCE OF DIFFERENT VARIETIES OF SORGHUM. International Journal of Research -GRANTHAALAYAH, 9(2), 1-10.

https://doi.org/10.29121/granthaa layah.v9.i2.2021.2854

Received Date: 25 December 2020

Accepted Date: 10 February 2021

\section{Keywords:}

Germination

Sprout

Nutritive Value

Varieties

\section{ABSTRACT}

The hydroponic fodder yield performance evaluation of different varities of sorghum was conducted in green house of Wollega University.. Three experiments were conducted. The first was to observe effects of irrigation frequency. The second one was undertaken to evaluate four sorghum varieties (Lalo, Chemeda, Gamadi and Dano) on fodder yield, yield related components and nutritive values. The third experiment was done to determine the appropriate date of harvest for biomass yield and agronomic traits. Complete randomized design (CRD) was employed to conduct the experiment with three replications. The results showed that there was no significant difference $(p>0.05)$ between treatments on Dry matter yield ( $\mathrm{t} / \mathrm{ha}$ ), Leaf Weight ( $\mathrm{t} / \mathrm{ha}$ ), Root weight ( $\mathrm{t} / \mathrm{ha}$ ) and Plant height $(\mathrm{cm})$ as effect of frequency of watering at $2 \mathrm{hr}, 3 \mathrm{hr}$ and $4 \mathrm{hr}$ interval but, significant difference $(\mathrm{p}<0.05)$ among varieties of sorghums as an effect of frequency of irrigation on Fresh yield(t/ha), Plant height $(\mathrm{cm})$ and leaf to root ratio (LRR\%).The lowest average fresh yields were harvested at 7 th days after planting and consistently increased until 17 th days of planting. The highest plant heights were observed at 17 days while the lowest was observed at 7th days of harvesting. Except for dry matter (DM), Ash and crude protein $(\mathrm{CP})$, there were significant differences $(\mathrm{P}<0.05)$ in neutral detergent fiber (NDF), acid detergent fiber (ADF), acid detergent lignin (ADL) and in vitro dry matter digestibility contents of the sorghum varieties. The Sorghum variety, Gamadi contained the highest CP (13.29\%) and lowest Acid detergent lignin contents. The Sorghum variety, Chemeda showed best in vitro DM digestibility (73.24\%). Harvesting hydroponic sorghum at 17 days after planting gave the best biomass yield ( $t / h a)$, LRR and Plant height $(\mathrm{cm})$; showing the increase in biomass as time of harvesting increases. Among the tested varieties of sorghum a variety, Dano best for biomass yield among the others.

\section{INTRODUCTION}

In Ethiopia livestock plays a major role for food security, particularly small holders and marginal farmers (Shapiro et al., 2015). Livestock sector contribute 15-17\% of national GDP and 35- 49\% of agricultural GDP, and 37$87 \%$ of the household incomes in the country including monetary values and the non-marketed services (traction and manure) in Ethiopia (IGAD, 2010). Livestock also plays an important role in urban and peri-urban areas for the

(C) 2021 The Author(s). This is an open access article distributed under the terms of the Creative Commons Attribution License, which permits unrestricted use, distribution, and reproduction in any medium, provided the original author and source are credited. 
poor evoking a living out of it and for those involved in commercial activities (Ayele et al., 2003). Hence, livestock remains as a pillar for food security, human nutrition and economic growth of the county (Shapiro et al., 2015). However, livestock production has mostly been subsistence oriented and characterized by low reproductive and production performance. This is mainly attributed to shortage of feed in quality and quantity (Malede, 2013, Tolera, 2007, Alemayehu, 2002, Kassahun et al., 2016).

The increasing demand for cropland to produce food for human reduced the area of land available for natural grazing and forges production (Alemayehu, 2002). During dry season the main feed resources are standing hays and crop residues in the country (Kassahun et al., 2016). Because of these, the chance of obtaining green fodder for livestock is minimal in the country. Green fodder is an essential component of the ruminants' ration to enhance their productive and reproductive performance (Dung et al., 2010, Shah et al., 2011). On the other hand there is severe shortage of feed for urban dairy production in almost all towns of Ethiopia. But, unlike monogastric animals, ruminants cannot be sustained on cereal grains alone. Due to the above constraints and the problems faced in the conventional method of fodder cultivation, hydroponics forage production is an alternative technology to grow fodder for farm animals (Naik, 2014; Naik and Singh, 2014 and Naik et al., 2015, Rodriguez et al., 2004).

Hydroponics technique can meet the growing nutrients requirement for livestock feed with suitable prices, in addition to guarantee a constant production of high quantity of green forage throughout the year and can be applied without requiring extensive land and can be source of green fodder because of its short growth period (Mooney, 2005). It has high feed quality that is rich with proteins, fibers, vitamins, and minerals (Bhise et al., 1988; Chung et al., 1989) with health beneficial effects on animals (Boue et al., 2003). This study was, therefore, designed with objective of evaluating hydroponics fodder yield performance and nutritive values of different Sorghum varieties.

\section{MATERIALS AND METHODS}

\subsection{EXPERIMENTAL SITE}

The experiment was conducted in green house of Wollega University which is located in East Wollega Zone of Oromia Regional state, Western Ethiopia at $328 \mathrm{~km}$ distant west of Addis Ababa, the capital city of the country. The geographical coordinates of the area is $10^{\circ} 0^{\prime} 0^{\prime \prime} \mathrm{N}$ latitude and $37^{\circ} 30^{\prime} 0^{\prime \prime} \mathrm{E}$ longitude. The average air temperature of the area is $21^{\circ} \mathrm{C}$. The area receives a minimum and maximum rainfall of $1376 \mathrm{~mm}$ and $2037 \mathrm{~mm}$, respectively and the average annual rain fall is $1706 \mathrm{~mm}$. Altitude of the area ranges from 1200-2342 $\mathrm{m}$ above sea level (Firehiwot et al., 2018).

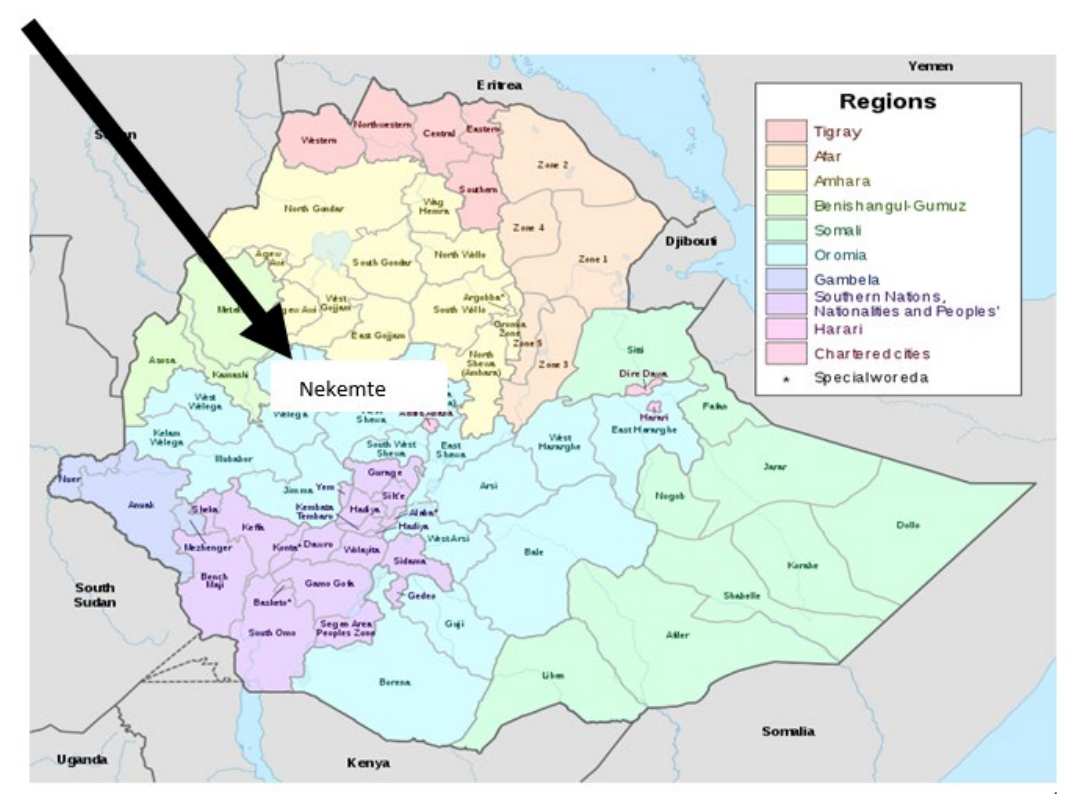

Figure 1: Map showing the locations of the study area. 


\subsection{PREPARATION OF PLANTING MATERIAL}

Different varieties of sorghum grains were obtained from Bako Agricultural research center of the country. Before emancipation of the experiment, the seeds were cleaned from debris and other foreign materials and were subjected to germination test to check for viability and the planting trays were also cleaned properly before use. The average temperature and humidity inside the green house was set at 220c (16 - 280C) temperature and $68 \%$ (52$80 \%)$ relative humidity. Thereafter, sprouted seeds were spread on the hydroponic tray at the rate of 190 gram seeds per tray. Trays were irrigated manually with tap water, frequency of watering of the seeds were done for identification of appropriate frequency of watering for sorghum varieties at 2 hour, 3 hour and 4 hour intervals of day time.

Frequency of Watering and Hydroponics Fodder Yield test of Sorghum Varieties: The study on frequency of watering was conducted for seventeen consecutive days. This was the beginning of the experiment before starting harvesting dates experiment of sorghum varieties. The treatments were formulated based on previous experiment reports in which seeds on trays irrigated manually with tape water twice a day i.e. Early in the morning and late in the afternoon (Ghazi N et.al, 2011).

Treatments for frequency of watering experiment: four varieties of sorghum (Lalo, Chemeda, Gemedi and Dano) were tested for frequency of watering at 2, 3 and 4 hours interval per day for 1 minute.

Harvesting Dates and Hydroponic Fodder Yield test of Sorghum Variety: The experiment was terminated at 17 th day of sowing. At harvest time, the following data were recorded per tray: total fresh and dry matter yield of fodder and ratio of produced green fodder to the initial planted seeds weight were computed. A representative fresh plant samples (About 200 grams) from every tray were taken at harvest and dried at $105^{\circ} \mathrm{C}$ in the oven for 48 hours for DM yield determination.

Harvesting dates experiment: to test the best harvesting date samples were taken at 7th, 9th, 11th, 13th, 15th, and 17 th day of sowing for biomass and chemical composition analysis.

\section{Agronomic Data Taken}

1) Leaf weight (grams): During harvesting two hundred gram of plants weight were taken per tray and leaves were trimmed using razor blade and all the leaves weighed using a weighing

Balance and the data were recorded. Then the total weight of leafs per tray was calculated by converting the leaves weighed calculated from a sample taken $200 \mathrm{~g}$ multiply to Total fodder weight then divided by two hundred gram of plants weight gives total leaf yield weight.

2) Root weight (grams): During harvesting two hundred gram of plants weight the roots were trimmed using razor blade and all the roots were quantified using a weighing Balance and the data were recorded. Then the total weight of roots per tray was calculated by converting the roots weighed calculated from a sample taken $200 \mathrm{~g}$ multiply to Total fodder weight then divided by two hundred gram of plants weight gives total root yield weight.

3) Total Fodder Yield: At harvesting total weight of green fodder obtained was calculated by taking fodder and tray weight together. The tray weight of subtracted as follows:

Total fodder weight $=$ fodder and tray weight - tray weight

\subsection{CHEMICAL ANALYSIS}

Partial DM was determined by drying the samples at $65^{\circ} \mathrm{C}$ in oven for $48 \mathrm{hr}$ (Fazaeli et al., 2012). After drying each part of the samples ground to pass $1 \mathrm{~mm}$ mesh screen sieve and stored for chemical analysis and in vitro DM digestibility (Hande et al., 2014). Hydroponic samples were analyzed for DM, Nitrogen and ash according to the procedures of (AOAC, 2000). Crude protein (CP) was calculated as $\mathrm{N} \times 6.25$ (AOAC, 1990). Neutral detergent fiber (NDF), acid detergent fiber (ADF) and acid detergent lignin (ADL) were determined according to (Van Soest et al., 1991) and In vitro DM digestibility was determined according to two-stage Tilley and Terry (1963) technique as modified by Van Soest et al., (1991) 


\subsection{STATISTICAL ANALYSIS}

The data on biomass yield and yield components and chemical compositions were analyzed using the statistical package, (SAS, 2008). Whenever the ANOVA declares significant difference among treatments, Tukey Honestly Significant Difference tests at $\alpha=0.05$ was used to compare means. The model used in both experiments was:

Yijk $=\mu+i+i j k$, where, $\mu=$ overall mean of the population; $i=$ the where, $\mu=$ overall mean of the population; $i=$ the ith treatment effect and ijk=random error associated with yij.

\section{RESULTS AND DISCUSSION}

Effect of Frequency of Watering on Fodder Yield and Related Traits: The result of effect of frequency of watering on hydroponic fodder yield and yield related agronomic trait of different Sorghum varieties is presented in Table 1. The result showed the fresh biomass yield ( $t / h a)$ and leaf to root ratio (LRR) have shown significant variation (Ps 0.05 ) among the frequency of watering treatment tests whereas the dry matter yield, leaf weight, plant height and root weight were similar $(\mathrm{P} \geq 0.05)$ along all frequency of watering.

Table 1: Effect of frequency of irrigation on Biomass yield and yield related components of sorghum varieties.

\begin{tabular}{|c|c|c|c|c|c|}
\hline Parameters & 2 hours & 3 hours & 4 hours & SEM & P-level \\
\hline Fresh yield (t/ha) & $93.39^{\mathrm{a}}$ & $85.118^{\mathrm{b}}$ & $95.16^{\mathrm{a}}$ & 1.398 & $* * *$ \\
\hline Dry matter yield (t/ha) & 13.08 & 12.66 & 12.93 & 0.501 & $\mathrm{NS}$ \\
\hline Leaf Weight (t/ha) & 5.51 & 5.13 & 5.80 & 0.295 & $\mathrm{NS}$ \\
\hline Plant height (cm) & 9.75 & 9.43 & 9.71 & 0.219 & NS \\
\hline Root weight (t/ha) & 7.57 & 7.53 & 7.46 & 0.366 & NS \\
\hline LRR & $0.74^{\mathrm{a}}$ & $0.69^{\mathrm{b}}$ & $0.78^{\mathrm{a}}$ & 0.023 & $*$ \\
\hline
\end{tabular}

*** $=\mathrm{P} \leq 0.001,{ }^{*} \mathrm{P} \leq 0.05, \mathrm{NS}=$ non-significant, DMY = Dry matter yield; SE = Standard error; LRR= Leaf Root Ratio $\mathrm{t} / \mathrm{ha}=$ tone per hectare; $\mathrm{a} \mathrm{b}=$ Means with different letter superscript within rows are significantly different

The effect of varieties on forage yield and Yield Related Components: The effect of different sorghum varieties on yield and yield related component is given in Table 2. The average green fodder yields were 98.5, 58.2, 86.4, and 121.9 t/ha for one production cycle (at 17th days), for Lalo, Chemeda, Gamadi and Dano varieties respectively. The result of measured parameters on Fresh yield $(\mathrm{t} / \mathrm{ha})$, Plant height $(\mathrm{cm})$ and LRR (\%) have shown significant $(\mathrm{p}<0.05)$ difference among varieties. The result of this study also has shown that, Dano yielded the highest fresh weight of green fodder than other varieties tested and the least was obtained from Chemeda variety of sorghum. The result also revealed the measured parameters in terms of Dry matter yield ( $t / h a)$, Leaf Weight ( $t / h a)$ and Root weight $(\mathrm{t} / \mathrm{ha})$ didn't have shown significant difference $(\mathrm{P} \geq 0.05)$ among varieties.

Table 2: Effect of Sorghum varieties on biomass yield and yield related components

\begin{tabular}{|c|c|c|c|c|c|c|}
\hline Parameters & Lalo & Chemeda & Gamadi & Dano & SEM & P-level \\
\hline Fresh yield (t/ha) & $98.47^{\mathrm{b}}$ & $58.21^{\mathrm{d}}$ & $86.35^{\mathrm{c}}$ & $121.85^{\mathrm{a}}$ & 1.62 & 0.0001 \\
\hline Dry matter yield (t/ha) & 12.88 & 13.43 & 13.13 & 12.11 & 0.58 & 0.4328 \\
\hline Leaf Weight (t/ha) & 5.86 & 5.02 & 5.72 & 5.32 & 0.34 & 0.3064 \\
\hline Root weight (t/ha) & 7.46 & 8.41 & 7.41 & 6.79 & 0.42 & 0.0856 \\
\hline LRR & $0.79^{\mathrm{a}}$ & $0.61^{\mathrm{b}}$ & $0.78^{\mathrm{a}}$ & $0.78^{\mathrm{a}}$ & 0.03 & 0.0001 \\
\hline Plant height (cm) & $11.64^{\mathrm{a}}$ & $6.78^{\mathrm{c}}$ & $8.20^{\mathrm{b}}$ & $11.89^{\mathrm{a}}$ & 0.25 & 0.0001 \\
\hline
\end{tabular}

DMY = Dry matter yield; SE = Standard error; LRR= Leaf Root Ratio t/ha = tone per hectare; $\mathrm{a} b \mathrm{c} \mathrm{d}=$ Means with different superscript within the rows show significant difference $(\mathrm{P}<0.05)$

Effect of Varieties on hydroponic Fodder Chemical Composition: The nutrient compositions of sorghum hydroponic fodder and sorghum grain are presented in Table 3. There were differences among treatments in chemical composition of sorghum varieties. The study revealed a slight increment in Crude protein and ash content of hydroponic fodder than the normal grain, but the differences were insignificant $(\mathrm{P} \geq 0.05)$, among them the varieties. 
Table 3: Effect of grain and hydroponic Sorghum varieties on chemical composition of the Fodder Sorghum varieties

\begin{tabular}{|c|c|c|c|c|c|c|c|}
\hline Parameters & Grain & Lalo & Chemeda & Gamadi & Dano & SEM & P-Value \\
\hline DM & 92.43 & 90.87 & 91.82 & 91.75 & 92.21 & 0.5480 & NS \\
\hline Ash & 1.69 & 2.48 & 2.18 & 2.32 & 2.30 & 0.1799 & NS \\
\hline CP & 12.13 & 12.31 & 12.79 & 13.29 & 12.49 & 0.3706 & NS \\
\hline NDF & $24.98^{\mathrm{c}}$ & $49.52^{\mathrm{a}}$ & $40.34^{\mathrm{b}}$ & $48.28^{\mathrm{a}}$ & $49.39^{\mathrm{a}}$ & 1.0028 & $* * *$ \\
\hline ADF & $7.04^{\mathrm{c}}$ & $19.13^{\mathrm{a}}$ & $12.26^{\mathrm{b}}$ & $18.11^{\mathrm{a}}$ & $19.43^{\mathrm{a}}$ & 0.7112 & $* * *$ \\
\hline ADL & $4.71^{\mathrm{a}}$ & $4.17 \mathrm{~b}^{\mathrm{a}}$ & $3.82 \mathrm{~b}^{\mathrm{b}}$ & $3.48^{\mathrm{b}}$ & $4.05^{\mathrm{ab}}$ & 0.1543 & $* *$ \\
\hline IVDMD & $82.78^{\mathrm{a}}$ & $66.30^{\mathrm{c}}$ & $73.24^{\mathrm{b}}$ & $68.30^{\mathrm{c}}$ & $65.85^{\mathrm{c}}$ & 0.9028 & $* * *$ \\
\hline Hemicellulose & $17.94^{\mathrm{c}}$ & $30.40^{\mathrm{a}}$ & $28.08^{\mathrm{b}}$ & $30.17 \mathrm{~b}^{\mathrm{ab}}$ & $29.96^{\mathrm{b}}$ & 0.4534 & $* * *$ \\
\hline Cellulose & $2.33^{\mathrm{c}}$ & $14.96^{\mathrm{a}}$ & $8.44^{\mathrm{b}}$ & $14.63^{\mathrm{a}}$ & $15.38^{\mathrm{a}}$ & 0.7821 & $* * *$ \\
\hline
\end{tabular}

*** $\mathrm{P} \leq 0.001, \mathrm{DM}=$ Dry matter; NDF = Neutral detergent fibers; ADF = Acid detergent fiber; $\mathrm{CP}=$ crude protein; $\mathrm{ADL}=$ Acid detergent lignin; IVDMD = In-vitroDry matter digestibility; SE = Standard error; a b c Means with different superscript letters differ significantly at $\mathrm{P} \leq 0.05$

The NDF and ADF contents of all sorghum hydroponic fodder varieties highly $(\mathrm{P} \leq 0.05)$ varied than the NDF and ADF content of the non-sprouted grain and significant differences $(P \leq 0.001)$ were also observed among varieties. Higher $(\mathrm{P} \leq 0.001)$ level of ADL and IVDMD content is observed from the non-sprouted grain. The ADF values ranged from $12.3-19.4 \%$ for all sorghum varieties. The in vitro DM digestibility of the grain was significantly higher $(\mathrm{P} \leq 0.001)$ than the sprouted forages.

Effect of Date of Harvesting: The result of effect of date of harvesting on hydroponic fodder yield and yield related a component is given in Table 4. There were differences among treatments in fodder yield and yield related traits. The overall average fresh fodder yields at 7, 9, 11, 13, 15 and 17 days of harvesting were 55.2, 58.9, 69.1, 88.6, 105 and $124.3 \mathrm{t} / \mathrm{ha}$, respectively. The highest biomass yield was observed at 17 th days of harvesting; indicating the longer harvest time will result in higher biomass production.

Table 4: Effect of date of harvesting on hydroponic sorghum fodder yield and Yield Related Components Dates of harvesting

\begin{tabular}{|c|c|c|c|c|c|c|c|c|}
\hline & \multicolumn{6}{|c|}{ Dates of harvesting } & & \\
\hline Parameters & 7 day & 9 day & 11 day & 13 day & 15 day & 17 day & SEM & SL \\
\hline Fresh yield (t/ha) & $55.23^{\mathrm{e}}$ & $58.87 \mathrm{e}$ & $69.07^{d}$ & $88.63^{c}$ & $105^{b}$ & $124.27^{a}$ & 1.79 & *** \\
\hline Dry matter yield (t/ha) & $17.7 \mathrm{a}$ & $18.17^{\mathrm{a}}$ & $14.17 \mathrm{~b}$ & $14.5^{b}$ & $13.63^{\mathrm{b}}$ & $13.83^{\mathrm{b}}$ & 0.42 & $* * *$ \\
\hline Leaf Weight (t/ha) & $4.64 c$ & $5.46^{\mathrm{abc}}$ & $5.04^{\mathrm{bc}}$ & $5.95^{\mathrm{abc}}$ & $6.06^{\mathrm{ab}}$ & $6.57^{a}$ & 0.28 & $* * *$ \\
\hline Root weight (t/ha) & $13.03^{\mathrm{a}}$ & $12.7^{\mathrm{a}}$ & $9.13^{b}$ & $8.53^{b c}$ & $7.57^{\mathrm{c}}$ & $7.27^{c}$ & 0.27 & $* * *$ \\
\hline LRR & $0.36^{\mathrm{e}}$ & $0.43^{\mathrm{de}}$ & $0.55^{\mathrm{cd}}$ & $0.70^{\mathrm{bc}}$ & $0.8^{\mathrm{ab}}$ & $0.91^{\mathrm{a}}$ & 0.03 & $* * *$ \\
\hline Plant height $(\mathrm{cm})$ & $1.53^{\mathrm{e}}$ & $2.23 \mathrm{e}$ & $4.43^{d}$ & $7.43^{\mathrm{c}}$ & $10.4^{b}$ & $13^{a}$ & 0.20 & *** \\
\hline
\end{tabular}

*** = significant at $\mathrm{P} \leq 0.001, \mathrm{DMY}=$ Dry matter yield; $\mathrm{SE}=$ Standard error; $\mathrm{LRR}=\mathrm{Leaf}$ root Ratio $\mathrm{t} / \mathrm{ha}=$ tone per hectare; $\mathrm{a} b \mathrm{cde}=$ Means with different letter superscripts differ at $\mathrm{P} \leq 0.05$ letters within

The present results have also shown that there was significant difference among the treatments in dry matter yield. The average dry matter yield at 7,9,11,13, 15 and 17 date of harvesting were 17.7, 18.2, 14.2, 14.5, 13.6 and 13.8t/ha, respectively. Longer harvested time increase biomass production but decrease dry mater and dry fodder yield. The original sorghum grains had higher DM values than sprouted sorghum

There were significance $(\mathrm{P} \leq 0.05)$ differences among treatments in plant height as a result of date of harvesting. For 7, 9, 11, 13, 15 and 17 date of harvesting, the mean plant heights recorded were 1.5, 2.2, 4.4, 7.4, 10.4 and $13 \mathrm{~cm}$, respectively. Biomass production of sorghum hydroponic fodder was significantly different on harvest time and varieties. There were also significant differences $(\mathrm{P} \leq 0.05)$ among treatments in plant leaf as influenced by dates of harvesting. This could be due to increase in process of photosynthesis until nutrient in the seed lost. The 17 days harvest time increased the plant leaf significantly $(\mathrm{P}<0.05)$. There were also differences among treatments in LRR. 
Since plant LRR is the ratio of plant leaf to plant root, as harvesting time increase the root weight decreases as compared to leaf weight and hence the plant harvested at 17 th day have higher plant LRR.
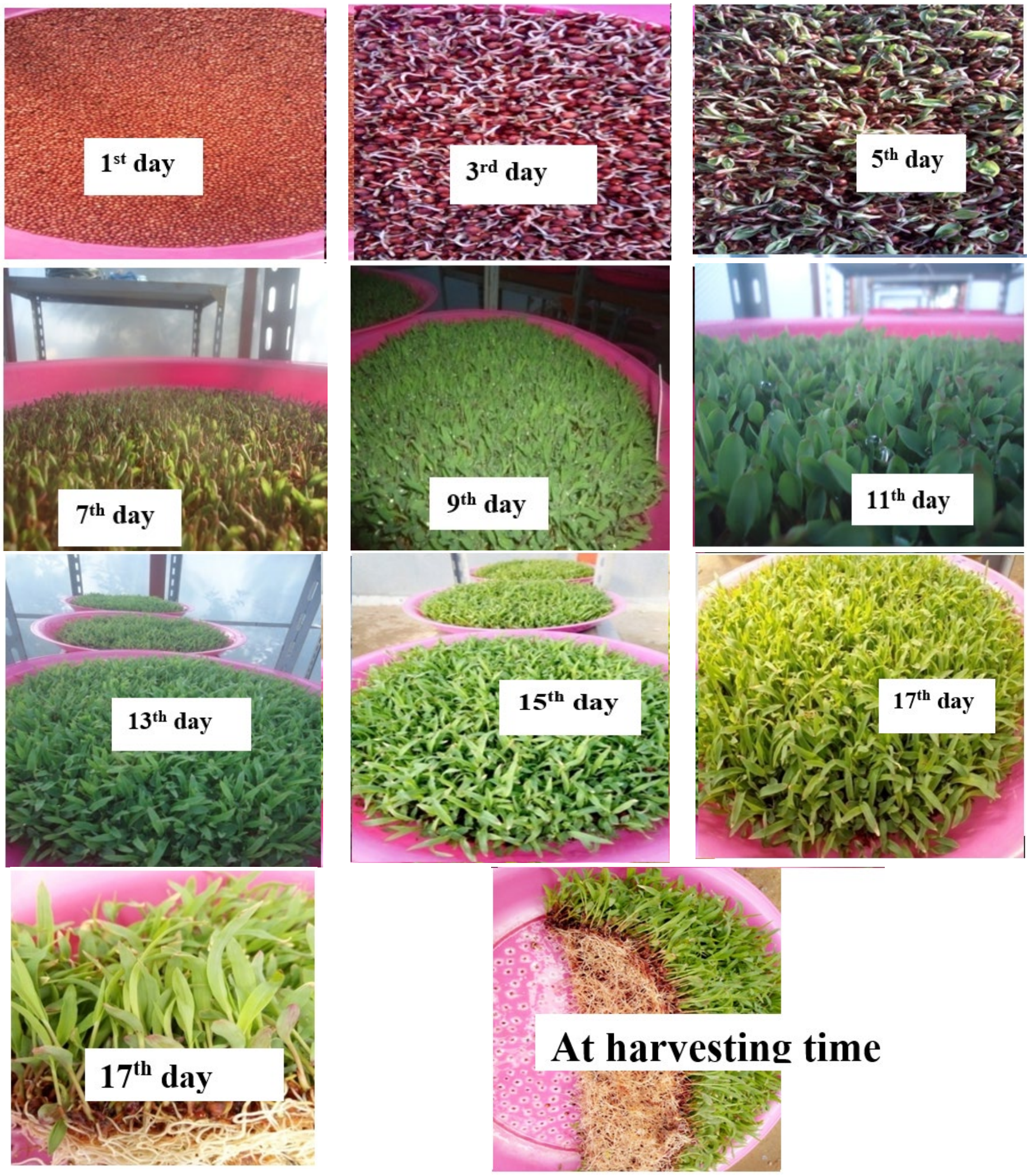

Figure 6: Hydroponic sorghum sprouts showing stages of growth from 1st day to 17th day 
Zelalem Garuma, and Kassahun Gurmessa

\section{DISCUSSION}

The frequency watering test result showed that twice watering per day has resulted a better biomass yield, root height, leaf weight and LRR. Four varieties of sorghum (Lalo, Chemeda, Gemedi and Dano) were evaluated to test for better performance in hydroponic fodder yield and nutritive value. Fresh biomass, plant heights and LRR result showed significant difference ( $\mathrm{P} \leq 0.001)$ among varieties. The highest hydroponic biomass $(121.85 \mathrm{t} / \mathrm{ha})$ is obtained from a variety called Dano and the least (58.2 t/ha) was recorded from Chemeda and these varieties also has shown similar trend in plant height and LRR result. Other parameters like DM content, leaf weight and root weight records were similar $(\mathrm{P} \geq 0.05)$ among the four varieties. Similar results that difference in variety result in difference in biomass were also reported elsewhere by different scholars in different countries (Cuddeford., 1989, Chavan and Kadam, 1989, Ghazi et al. 2011). The average plant height was 11.6, 6.9, 8.2, and 11.9 among varieties of sorghum (Lalo, Chemeda, Gamadi and Dano) respectively.

The nutrient contents of experimental sorghum varieties were also tested and the result recorded were similar $(\mathrm{P} \geq 0.05)$ for $\mathrm{CP}$ and Ash content in all hydroponic fodder varieties of sorghum and their respective non sprout grains. But, the ash and CP contents of all sprouted varieties were relatively higher than the non-sprouted grain varieties which are similar with reported results of Dung et al., (2010). The increase in protein content may be attributed to the loss in dry weight, particularly carbohydrates, through respiration during germination and thus longer sprouting time might be responsible for the greater losses in dry weight and increasing trend in protein content. According to Morgan et al. (1992) changes in protein contents occur rapidly from day 4 corresponding with the extension of the radical root, which allows the mineral uptake and studies show the absorption of nitrates facilitates the metabolism of nitrogenous compounds from carbohydrates reserves, thus increasing levels of CP (Naik et al., 2012a, Morgan et al. 1992, Chavan and Kadam, 1989). The average CP content varied from 12'3\% to $12.79 \%$ which is similar with other reported records of sprouted fodder CP content of 13.27\% reported (Rachel J.et al. 2015). Chrisdiana, 2014 evaluated the CP composition of sprouted sorghum varieties and reported the result that reaches from 18.68 to $26.68 \%$ which was higher than the present value. The differences in reported result could arise from difference in varieties of the sorghum crop used. The NDF and ADF contents of all hydroponically grown sorghum varieties were significantly $(\mathrm{P} \leq 0.001)$ higher than the NDF and ADF content of the non-sprouted grain and among varieties. Dung et al., (2012) explains that the fiber content is mostly derived from root and seed husk due to the maturation process and endosperm formation with the increasing value of ADF and NDF in plants, the organic matter content decreased. According to Singh and Oosting (1992), feeds containing NDF values of less than $45 \%$ are classified as high quality, those with values ranging from $45 \%$ to $65 \%$ as medium and those with values higher than $65 \%$ as having low quality. In the present study, the NDF content of the sorghum variety Chemeda fulfills high quality forage criteria i.e. below $45 \%$; the rest varieties were in the medium quality classes. The ADF values ranged from $12.3-19.4 \%$ for all sorghum varieties which are in status which do not impair digestibility. Higher $(\mathrm{P} \leq 0.001)$ level of ADL and IVDMD content is observed from the non-sprouted grain. The in vitro DM digestibility of the grain was significantly higher than the sprouted forages and the difference among the varieties were significant $(\mathrm{P} \leq 0.001)$ this might be due to the residue of the previous grain hulls and the root structure of the sprouted sorghum fodder.

The result of effect of date of harvesting on hydroponic fodder yield and yield related a component showed significant $(\mathrm{P} \leq 0.001)$ differences among treatments in hydroponic fodder yield. The overall average fresh fodder yields at 7, 9, 11, 13, 15 and 17 days of harvesting were 55.2, 58.9, 69.1, 88.6, 105 and 124.3 t/ha, respectively. The highest biomass yield was observed at 17th days of harvesting; indicating the longer harvest time will result in higher biomass production. Similar scenarios were also reported for different crops in different areas of the world (Cuddeford, 1989, Firehiwot G.et al., 2018, Peer and Leeson, 1985, Dung et al., 2010, Chrisdiana, 2018). Commercial sprouts growers have reported fresh weight increases of 6 and 10 fold i.e., $1 \mathrm{~kg}$ of seed yielding about 6-10 kg of fresh sprouts (Sneath and McIntosh, 2003). While trial yields from present study indicated a 2.5- 5.8 fold increase in fresh weight with sprouting of grains.

The study on time of harvest test also indicated the longer harvesting time increase biomass production but decrease dry mater and dry fodder yield. This gradual decrease in DM during growth time process might be due to leaching and oxidation of nutrients from the seeds. The DM content in sorghum varieties sprouts showed a loss which reflected a lower value than the original sorghum grain. Most of the losses in DM in the sprouts were as a result of respiration, an energy requiring process which shows why there was lower energy on a DM basis in the sprouts. The original sorghum grains had higher DM values than sprouted sorghum. According to reports of Sneath and McIntosh,

International Journal of Research -GRANTHAALAYAH 
Evaluation of Hydroponic Fodder Performance of Different Varieties of Sorghum

(2003) during germination, DM is lost due to the increased metabolic activities of sprouting seeds; the energy for these metabolic activities is derived by partial degradation and oxidation of starch.

\section{CONCLUSION}

The hydroponics sorghum fodder increased crude protein, Neutral Detergent Fiber and Acid Detergent Fiber content compared to the grains. Among sorghum varieties studied Dano is better for high fresh biomass yield with relatively good nutritive value harvested at 17 th date of harvest. The result also showed increase in weight of forage than the normal grain and biomass increases as date harvest increases.

\section{SOURCES OF FUNDING}

This research received no specific grant from any funding agency in the public, commercial, or not-for-profit sectors.

\section{CONFLICT OF INTEREST}

The author have declared that no competing interests exist.

\section{ACKNOWLEDGMENT}

The authors would like to thank Wollega University, Jimma Geneti District office of livestock and Fishery Development for sponsoring the study and Holeta Agricultural Research for allowing us their laboratory facilities to evaluate the nutritional contents of samples.

\section{REFERENCES}

[1] Adugna Tolera, (2012). Potential for Development of Alternative Feed Resources in Ethiopia. An Assessment Report prepared for ACDI/VOCA. Addis Ababa Ethiopia.pp20

[2] AOAC.(1999). Official methods of analysis. Association of Official Analytical Chemists, Inc. Arlington, Virginia, USA.

[3] AOAC. (2000). Official Methods of Analysis. 17th Ed. Association of Official Analytical Chemists, Gaithersburg, MD.

[4] Alemayehu Mengstu, (2002). Forage production in Ethiopia: A case study with implications of livestock production. ESAP (Ethiopian Society of Animal Production), Addis Ababa, Ethiopia. pp. 1-3.

[5] Ayele, Solomon, Assegid Workalemahu, Jabbar, M.A., Ahmed, M.M., and Belachew Hurrisa, (2003). Livestock marketing in Ethiopia: Performance and Development Initiatives. Socioeconomic and Policy Research Working Paper 52

[6] Bhise V, Chavan J, S Kadam, (1988)' Effects of malting on proximate composition and in vitro protein and starch digestibilities of grain sorghum. Journal of Food Science Technology 25(6): 327-329

[7] Bill C.and Pavel R., (2002). Growing cattle feed hydroponically. Meat and Livestock Australia

[8] Boue S, T Wiese, S Nehls, M Burow, S Elliott, C Carterwientjes, B Shih, J McLachlan, and T. Cleveland, (2003). Evaluation of the estrogenic effects of legume extracts containing phytoestrogens. Journal Agriculture Food Chemistry 51(8):2193-2199

[9] Chandra P and M J. Gupta, (2003). Cultivation in hi-tech greenhouses for enhanced productivity of natural resources to achieve the objective of precision farming. In: Precision Farming in Horticulture (Singh $\mathrm{H} \mathrm{P}$, Singh, Gorakh, Samuel J C and R K Pathak, (Eds). pp 64-74

[10] Chavan J, and S S Kadam, (1989). Nutritional improvement of cereals by sprouting Critical Reviews in Food Science and Nutrition 28(5): 401-437

[11] Chrisdiana R,. (2018). Quality and Quantity of Sorghum Hydroponic Fodder from different varieties and harvest time. IOP conf. ser., Earth Environ. Sci., 11:21-24. 
[12] Chung T Y, Nwokolo E N and J S Sim, (1989). Compositional and digestibility changes in sprouted barley and canola seeds. Plant Foods for Human Nutrition 39: 267-278

[13] Cuddeford D, (1989). Hydroponic Grass Journal of the British Veterinary Association 11(5): 211-214

[14] Dung D D, Godwin I R, and J V Nolan, (2010a). Digestive characteristics, ammonia nitrogen and volatile fatty acids levels in sheep fed oaten chaff supplemented with grimmett barley grain freeze-dried or fresh barley sprouts. Journal of animal and veterinary Advances 9 (19): 2493-2501

[15] Dung, D.D., Goodwin, I.R., and Nolan, J.V. (2010). Nutrient content in Sacco Digestibility of barley grain and sprouted barley. Journal of animal and veterinary Advances, 9(19), 2485- 24992.

[16] Fazaeli, H., Golmoihammadi, H.A., Tabatabayee, S.N. and Asghari-Tabrizi, M. (2012). Productivity and nutritive value of barley green fodder yield in hydroponic system. World Applied Sciences Journal, 16: 531-539.

[17] Firehiwot Girma, Diriba Diba, Kassahun Gurmessa and Diribe Kumsa(2018). Evaluation of Hydroponics Performance and Nutritive Value of Different Oat (A. sativa) Forage Varieties in Wollega University, Western Ethiopia. American-Eurasian Journal of Scientific Research 13 (3): 39-46

[18] Ghazi N. Al-Karaki and M. Al-Hashimi. (2011). Green Fodder Production and Water Use Efficiency of Some Forage Crops under Hydroponic Conditions. Volume 2012, Article ID 924672, 5 pages. doi:10.5402/2012/924672.

[19] Hande, I.A., S.T. Onur, B. Harun and Y.Y. Ismail, (2014). Effects of Harvesting Time on Nutritional Value of Hydroponic Barley Production. Turkish Journal of Agricultural and Natural Sciences Special Issue, 2: 2014

[20] IGAD (Intergovernmental Authority on Development), (2010). The contribution of livestock to the economies of IGAD member states. IGAD LPI working paper No. 02-11.

[21] Kassahun Gurmessa, Taye Tolemariam, Adugna Tolera, Fekadu Beyene, (2016). Production and Utilization of Crop Residues in Horro and Guduru Districts, Western Ethiopia. Food Science and Quality Management Vol.48, 2016.

[22] Malede B. (2013): Forage Agronomic Evaluation and Biological Compatibility on Grasse: Legume Intercropping in North Gondar Zone, Ethiopia. International Journal of Animal and Veterinary Advances, 5: 245-250.

[23] Mooney J. (2005). Growing cattle feed hydroponically. Meat and livestock Australia.30p.

[24] Morgan J, Hunter R R and R O'Haire, (1992). Limiting factors in hydroponic barley grass production In: Proc. 8th International Congress on Soilless Culture. Hunter's Rest South Africa pp: 241- 261

[25] Naik P K and N P Singh, (2013). Hydroponics fodder production: an alternative technology for sustainable livestock production against impeding climate change. Pp 70- 75

[26] Naik P K and N P Singh, (2014). Production and feeding of hydroponics green fodder Indian Farming 64 (7)

[27] Naik P K, Dhuri R B and N P Singh, (2011). Technology for production and feeding of hydroponics green fodder Extension Folder No 45/ 2011 ICAR Research Complex for Goa.

[28] Naik P K, Dhuri R B, Karunakaran M, Swain B K and N P Singh, (2014). Effect of feeding hydroponics maize fodder on digestibility of nutrients and milk production in lactating cows. Indian Journal of Animal Science 84(8), 880-883

[29] Naik P K, Dhuri R B, Swain B K and N P Singh, (2012a). Cost of production of hydroponics fodder maize In:Proc of 8th Biennial Animal Nutrition Association Conference on Animal Nutrition Research Strategies for Food Security November 28-30 2012 Bikaner Rajasthan India p12

[30] Naik P K, Dhuri R B, Swain B K and N P Singh, (2012b). Nutrient changes with the growth of hydroponics fodder maize. Indian Journal Animal Nutrition (29): 161-163

[31] Naik P K, Dhuri R B, Swain B K and N P Singh, (2013). Water management for green fodder production as livestock feed in Goa In Abstracts of International Conference on Water Management for Climate Resilient Agriculture held at Jalgaon Maharashtra India May 28-31 2012 Pp 126-127

[32] Naik P K, Swain B K and N P Singh, (2015). Production and Utilization of Hydroponics Fodder Indian Journal Animal Nutrition 32 (1): 1-9

[33] Naik, P.K., (2012a). Hydroponics technology for fodder production. ICAR News. 18: 4.

[34] Naik, P.K. and Singh, N.P., (2013). Hydroponics Fodder Production: An Alternative Technology for Sustainable Livestock Production against Impeding Climate Change. Indian Journal of Animal Sciences. ICAR Research Complex for Goa, Old Goa, Goa- 40340245

[35] Naik, P.K. and Singh, N.P., (2014). Production and feeding of hydroponics green fodder. Indian Farming. 64 (6): $42-44$. 
[36] Naik, P.K., Dhuri, R.B., Karunakaran, M., Swain, B.K. and Singh, N.P., (2014). Effect of feeding hydroponics maize fodder on digestibility of nutrients and milk production in lactating cows. Indian Journal of Animal Science. 84 (8): 880-883.

[37] Naik, P.K., Gaikwad, S.P., Gupta, M.J., Dhuri, R.B., Dhumal, G.M. and Singh, N.P., (2013b). Low cost devices for hydroponics fodder production. Indian Dairyman. 65: 68-72.

[38] Naik, P.K, Swain, B. K, Chakurkar, E., B and Singh N. P,. (2016a). Effect of seed rate on yield and proximate constituents of different parts of hydroponics maize fodder. Indian Journal of Animal Sciences 87(1): 109-12.

[39] Naik, P.K., Swain, B.K. and Singh, N.P., (2015). Production and Utilisation of Hydroponics Fodder. Indian Journal of Animal Nutrition. 2015. 32 (1): 1-9.

[40] Peer D J and S Leeson, (1985). Feeding Value of Hydroponically Sprouted Barley for Poultry and Pigs. Animal Feed Science and Technology (13): 183-190.

[41] Rachel Jemimah, E., Gnanaraj, P.T., Muthuramalingam, T., Devi, T., Babu, M. and Sundharesan, A., (2015). Hydroponic green fodder production-TANUVAS experience.

[42] SAS (Statistical Analysis System). (2008). The Little SAS® Book: A Primer, Fourth

[43] Edition, version 9.1.3. Statistical analysis system institute Inc., NC. USA.

[44] Shah, V.D., Makwana, M., and Sharma, S., (2011). Economics of production, processing and marketing of fodder crops in Gujarat. India Research Study No.144.

[45] Shapiro, B.I., Gebru, G., Desta, S., Negassa, A., Nigussie, K., Aboset, G. and Mechal, H. (2015). Ethiopia livestock master plan. ILRI Project Report. Nairobi, Kenya: International Livestock Research Institute (ILRI).

[46] Sneath, R. and McIntosh, F., (2003). "Review of hydroponics fodder production for beef cattle." North Sydney; Australia: Meat and livestock Australia Limited. Crops for the Purification of Aquaculture Wastewater and the Production of Fish Feed. American Journal of Agricultural and Biological Sciences 3(1): 364-378

[47] Tilley,J.M.A and Terry, R. A,. (1963). A two stage technique for invitrodigestion. Journal of British Grassland Society 18: 104.

[48] Van Soest,P.J., Robertson,J .B.,Lewis, B.A. (1991). Methods fordietary fiber, neutraldetergent fiber and nonstarch polysaccharides in relation to animalnutrition. Journal of Dairy Science, 74: 3583-3597. 